\title{
POLIGAMI SIRRI DAN DAMPAKYA TERHADAP MENTAL ISTRI DAN ANAK PERSEPEKTIF SIGMUND FREUD
}

\author{
Noer Azizah \\ UIN Maulana Malik Ibrahim Malang \\ azizahaqenje97@gmail.com
}

\begin{abstract}
Marriage is the best way to fulfill human nature, human desires, desire, and to continue generation. Therefore, marriage must be in accordance with the provisions of the Marriage Law, in order to obtain legal certainty and protection. Nowadays, many people tends to marriages with unregistered mariages way that occurs for the second or more mariages. This article examines the unregistered mariages polygamy and its impact on the wife's mentality by Sigmud Freud's perspective. The purpose of this study was to determine how to analyze Sigmund Freud's thoughts on the mental of his wife and children due to the impact of unregistered mariages polygamy. The research methodology by qualitative research methodology, data analysis techniques are qualitative descriptive techniques. The data obtained came from books, literary literature, and was strengthened from field research that came from interviews. The results showed that unregistered mariages polygamy had an impact on psychological burdens, namely the presence of shame, insecurity, the child felt less confident, bad child relationships and in long term would have an impact on mental health. However, when it is associated with the Sigmund Freud's perspective, not all people like that are considered weak mentality, because when linked in his opinion a person who can cope with stress and anxiety means that people have good mentality.
\end{abstract}

Keywords: Mental Health, Unregistered Mariages, Polygamy, Sigmund Freud Perspective

\section{Abstrak}

Pernikahan merupakan jalan terbaik untuk memenuhi tabiat manusiawi, menyalurkan hasrat, melampisakan gairah sesksualnya, dan melahirkan keturunan. Maka dari itu, pernikahan haruslah sesuai dengan ketentuan yang berlaku di Undang-undang perkawinan, supaya mendapat kepastian dan perlindungan hukum. Saat ini, kecenderungan yang terjadi pernikahan yang dilakukan dengan cara sirri, biasanya kecenderungan ini terjadi pada saat pernikahan seorang pria yang akan dilakukan kedua kalinya atau lebih. Artikel disini mengkaji tentang poligami nikah sirri dan dampaknya terhadap mental istri dengan perespektif Sigmud Freud. Tujuan penelitian ini adalah untuk mengetahui bagaimana analisa pemikiran Sigmund Freud terhadap mental istri dan anak akibat dampak dari poligami sirri. Metodelogi penelitian yang dipakai ialah dengan metodelogi penelitian kualitatif, teknis analisa data ialah teknik deskriptif kualitatif. Data yang diperoleh bersumber dari buku, 
literatur kepustakaan, serta diperkuat dari penelitian lapangan yang bersumber dari wawancara. Hasil penelitian menunjukkan bahwa poligami sirri berdampak pada beban psikis, yakni akan adanya rasa malu, minder, anak tersebut merasa kurang percaya diri, rusaknya pergaulan anak dan jika dibiarkan dalam jangka panjang akan berdampak terhadap ketidak sehatan mental seseorang. Namun ketika dikaitkan dengan aliran Sigmund Freud tidak semua orang yang seperti itu dianggap lemah mental, karena ketika dikaitkan menurut pendapatnya orang yang bisa mengatasi tekanan dan kecemasan berarti orang tersebut mentalnya masih dianggap baik.

Kata Kunci: Mental Kesehatan, Pernikahan Sirri, Poligami, Perspektif Sigmund Freud

\section{PENDAHULUAN}

Pernikahan adalah suatu yang sangat urgen dalam kehidupan manusia, tapi kita harus memperhatikan, pernikahannya sah atau tidak dalam pandangan syariat Islam dan Undang-undang perkawinan. Masalah pernikahan yang sering diperbincangkan oleh masyarakat muslim ialah poligami. Awal munculnya poligami bahkan sebelum Islam datang. Setelah Islam datang, praktek poligami yang diakomodir oleh Islam, akan tetapi Islam sendiri memberikan batasan dalam jumlah istri dan memberikan syaratsyarat yang harus dipenuhi jika ada yang ingin berpoligami.

Kondisi, situasi dan zaman yang semakin berkembang pencatatan perkawinan yang dulunya tidak penting sekarang menjadi urgen. Berdasarkan pasal 2 ayat (2) Undang-undang No. 1 tahun 1974 tentang pencatatan perkawinan bahwa: "tiap-tiap perkawinan dicatat menurut peraturan perundang-undangan yang berlaku". Kompilasi Hukum Islam (KHI) juga memperjelas terkait pencatatan perkawinan, dipertegas dalam pasal 5 ayat (1) tentang dasar-dasar perkawinan "agar terjamin ketertiban perkawinan bagi masyarakat islam, maka setiap perkawinan harus dicatat" (Aulia, 2011).

Namun kenyataannya, praktik perkawinan yang dilakukan di lingkungan masyarakat berbeda-beda, karena sepenuhnya tidak mengacu pada Undang-undang perkawinan yang mengharuskan adanya pencatatan, sehingga mereka tetap melangsungkan nikah di bawah tangan yang sah menurut agama. Masyarakat di Indonesia minim akan kesadaran terhadap pentingnya pencatatan perkawinan, dan pada akhirnya dampak negatif yang ditimbulkan akan meluas, menjadi korban yang sangat dirugikan baik kepada istri, ataupun terhadap anaknya. Umumnya yang terjadi di Negara kita terkait poligami, poligami yang dilakukan cenderung sirri. 
Huzaemah Tahido Yanggo berberdapat bahwa Nikah sirri dan nikah di bawah tangan adalah dua kata yang tidak ada kesamaaan arti. Nikah sirri ialah nikah dilakukan dengan cara rahasia, agar tidak ketahuan oleh orang lain, sedangkan nikah di bawah tangan ialah nikah yang masih dianggap sah oleh fiqih ketika memenuhi rukun dan syarat dalam pernikahan (Sopyan, 2011). Namun menurut saya pribadi nikah sirri dan nikah dibawah tangan ialah satu kesinambungan, karena orang yang melaukan perkawinan yang tanpa dicatat di Kantor Urusan Agama (KUA), terlebih perkawinan poligami, perkawinan inilah yang disebut dengan perkawinan poligami sirri, karena dilakukan secara sembunyi, dan tanpa diumumkan pada masyarakat umum.

Seorang laki-laki yang menikahi perempuan dengan cara nikah sirri, maka dengan seenaknya meninggalkan istri tanpa dibebani tanggung jawab, maka dari situ akan terbukanya peluang bagi laki-laki untuk melakukan tindakan kekerasan dalam rumah tangga (KDRT), kesulitan membuat akta kelahiran, terhalangnya pembagian waris dan hak nafkah, dampak psikis, serta mental yang dirasaka anak dan istri, dan masih banyak lagi dampak yang ditimbulkan. Sehingga penulis tertarik untuk meneliti lebih lanjut terkait poligami sirri dan dampak mental terhadap istri dan anak.

\section{Pembahasan}

\section{Definisi Poligami dan Dasar Hukum Menurut Hukum Positif}

Tidak asing lagi ditelinga kita mendengar kata pologami, secara etimologi poligami bermakna banyak yang berasal dari bahasa Yunani dan Ganos yang bermakna perkawinan. Sedangkan secara terminology, pologami yaitu seorang laki-laki yang menikahi istri lebih dari seorang. Sebagaimana dalam undang-undang No.1 tahun 1974 pasal 3, sebagaimana isinya "poligami ialah ikatan perkawinan dimana suami memiliki istri lebih dari seorang" (Suma, 2008). Sedangkan dalam hukum Islam sebagaimana yang termaktub dalam surat QS. An-Nisa' (4): 3, bahwa poligami ialah perkawinan yang lebih dari seorang, yang dengan persyaratan sampai empat wanita, bahkan ada yang memaknai batasan itu melampaui lebih dari empat orang perempuan atau istri.

Indonesia adalah Negara hukum, pastinya memiliki peraturan di berbagai bidang, seperti halnya dalam urusan perkawinan perilhal poligami. Sebagaimana mekanisme poligami, mulai dari batasan maksimal jumlah istri, alasan, sampai prosedur yang harus ditempuh oleh seorang yang akan berpoligami. Sebagaimana dalam undang-undang No.1 tahun 1974 dalam pasal 4 (1-2), dan pasal 41 PP No. 9 tahun 1975 (Tjitrusudibio, 1992): 


\section{Pasal 4}

1) Suami yang akan beristri lebih dari seorang, sebagaimana dalam pasal 3 ayat (2), yakni wajib mengajukan permohonan kepada pengadilan di daerah tempat tinggalnya.

2) Pengadilan tersebut layak memberikan izin kepada suami yang akan menikah lagi, apabila:

a. Istri tidak bisa menjalankan kewajibannya.

b. Terdapat cacat atau penyakit pada tubuh istri.

c. Istri mandul.

Pasal 5 yat 1

1) Agar bisa mengajukan permohonan ke pengadilan, maka harus memenuhi beberapa syarat:

a. Adanya persetujuan dari istri.

b. Adanya kepastian bahwa suami mampu menjamin keperluan istri dan anaknya.

c. Adanya jaminan bahwa suami bisa berlaku adil terhadap istri dan anaknya.

Dalam hukum poisitif nasional yang diterpakan di sejumlah putusan hakim di peradilan agama, ialah dengan menggunakan pedoman pernikahan, yang terbukukan dalam Kompilasi Hukum Islam (KHI), sebagaimana yang dijelaskan dalam pasal 56, 57, 58 tentang poligami (Departemen Agama RI, 2000):

\section{Pasal $56 \mathrm{KHI}$}

1) Suami yang hendak beristri lebih dari seorang harus mendapat izin dari pengadilan agama.

2) Mengajukan permohonan izin sebagaimana pada ayat (1) dalam bab VIII tentang peraturan pemerintah nomor 9 tahun 1975.

3) Perkawinan yang dilakukan dengan istri kedua ataupun selanjutnya tanpa izin dari pengadilan agama, maka tidak memiliki kekuatan hukum.

Pasal 57 KHI

Pengadilan agama hanya memberikan izin kepada suami yang akan beristri lebih dari seorang, apabila:

a. Istri tidak bisa menjalankan kewajiban sebagi istri.

b. Terdapat cacat badan atau penyakit yang tidak bisa disembuhkan.

c. Istri tidak bisa melahirkan.

Pasal 58 ayat (2)

2) Dengan tidak mengurangi ketentuan pasal 41 huruf $b$ tentang peraturan pemerintah nomor 9 tahun 1974, bahwa persetujuan istri atau istri-istri dapat diberikan dengan cara tulis atau lisan, akan tetapi sekalipun telah 
ada persetujuan tertulis, pengadilan agama tetap mempertegas dengan persetujuan lisan.

\section{Kedudukan Poligami Sirri menurut Hukum Positif}

Di mata masyarakat Indonesia poligami dikenal dengan sebutan perkawinan dibawah tangan/nikah sirri, yakni melaksanakan perkawinan tanpa adanya surat nikah dan izin dari pengadilan agama dimana ia tinggal. Mayoritas masyarakat muslim banyak yang tidak paham tentang pelanggran yang telah ditetapkan dalam undang-undang nomor 1 tahun 1974 tentang perkawinan. Mereka yang tidak paham menikahi seorang perempuan tanpa dicatatatkan di lembaga yang berwenang, yakni di Kantor Urusan Agama (KUA).

Poligami yang tidak dicatatkan dalam KUA maka perkawinan tersebut tidak sah secara undang-undang. Karena Undang-undang perkawinan tidak mengenal perkawinan dibawah tangan, sebagaimana yang dijelaskan dalam pasal 2 ayat (2) bahwa mensyaratkan pencatatan perkawinan. Maka dari itu, poligami sirri tidak sah menurut hukum walapun sah menurut agama dan memiliki kekuatan hukum, sehingga ada dampak negatif dengan rumah tangganya, mislanya dalam perihal, kekerasan rumah tangga, warisan, tidak diberikan nafkah yang layak dan lainnya. Ketika perihal yang tidak diinginkan terjadi maka pihak lembaga seperti pengadilan agama, KUA, tidak bisa menerima pengaduan dari masalah yang mereka.

Masih banyak lagi yang belum mengerti akan pentingnya pencatatan perkawinan, sebagian dari mereka bisa jadi hanya sekedar ikut-ikutan saja, menganggap yang sepele, hanya berfikir kalau hanya sebagai tradisi belaka. Mereka pun belum sepenuhnya paham bigitu pentingnya poligami atau nikah dengan cara yang sudah ditetapkan oleh peraturan yang sudah ada. Di mata hukum yang berlaku di negara hukum terkait keabsahan menikah, yakni harus dnegan cara mencatatkan ke lembaga yang berwenang dan mengikuti persyaratan yang sudah ditetapkan. Dengan demikian kedudukan hukum dari poligami sirri perihal pernikahannya dianggap tidak pernah terjadi karena tidak memilki ketetapan hukum.

\section{Dampak Poligami Sirri terhadap mental Istri dan Anak}

Setiap sesuatu yang kita lakukan pasti ada akibat yang kita rasakan. Sebagaimana dalam perkawinan pologami sirri yang mempunyai dampak dan akibat yang dirasakan kepada istri dan anak, apalagi perkawinan tersebut tidak memiliki kekuatan hukum yang dilakukan nikah di bawah tangan atau dengan cara nikah sirri, tentunya akan membawa akibat hukum yang sangat merugikan istri dan anak. Akibat dari poligami sirri maka akan berkibat: 
1. Istri tidak termasuk istri sah, sehingga tidak mempunyai hak untuk mendaptkan nafkah, tempat tinggal, warisan, dan harta gono-gini.

2. Anak tersebut bukan termasuk anak yang sah, sehingga anak tersebut kehilangan atas nama atau nasab bapaknya, pendidikan, nafkah lahir batin, dan warisan dari bapaknya. Tidak mempunyai hubungan hukum dengan bapaknya. Perihal ini berdampak pada jiwa si anak karena dianggap anak luar kawin, apalagi jika si ayah tidak pernah tahu akan nafkah kepada anaknya.

Bermacam akibat yang melanda kepada istri dan anak akan berdampak pada beban psikis, yakni akan adanya rasa malu, minder, kecewa, tekanan batin karena cemoohan dari masyarakat yang menganggap istri simpanan. Dan jika dibiarkan dalam jangka panjang akan berdampak terhadap ketidak sehatan mental seseorang. Rata-rata anak yang tumbuh dari penikahan poligami sirri, ketika sudah beranjak sekolah ketidak absahan status anak akan menimbulkan ketidak harmonisan dalam keluarga, anak tersebut merasa kurang percaya diri, rusaknya pergaulan anak. Dan jika problem dibiarkan dalam jangka panjang maka akan berakibat terhadap perkembangan mental mereka.

\section{Kesehatan Mental Persepektif Sigmund Freud}

Penggagas dari ilmuan yang sangat popular dikenal dengan kecerdasannya, ketidak puasaan dari doktrin yang diterimanya sebelum dia andil dalam meneliti sendiri, dialah Sigmund Freud, ia lahir di Cekoslovikia 6 Mei 1856. Tidak hanya diam disatu tempat untuk menambah ilmu pengertahuan, dia rasakan diberbagai tempat, yakni ke Wina, Australia. Disitulah ia gigih mempelajari kebudayaan dan hubungan tran budaya manusia, hingga dia semangat untuk membuat analisa dan penelitian secara lebih dalam.

Menurut Freud, manusa ialah dianggap sebaga realitas alamiah matearilistik yang mempunyai daya psiko-phisik, seluruh aktivitasnya bersumber dari apa adanya. Maka dari itu manusia yang sehat ialah manusia yang dianggap mekanisme psikisnya berjalan secara harmonis. Menurut teori analisinya manusia seperti gunung es di tengah-tengah samudra, jadi menurutnya manusia lebih banyak melakukan hal di luar kesadaran dibandingkan dengan hal yang disadari.

Psikoanalisa ialah yang dicetus oleh Sigmud Freud dan merupakan salah satu aliran besar dalam dunia psikologi. Dalam teori psikoanalisanya Freud menjelaskan tentang struktur kepribadian individu, struktur tersebut terbagi menjadi 3 (wordpres.com): 
1. Id, merupakan system kepribadian yang asli dan mendasar yang bersumber dari sejak lahir. Id tersebut ialah sebagai wadah untuk berkembangnya ego dan superego.

2. Ego, termasuk askpek psikologis yang berkembang dari id guna sebagai pengontrol kesadaran dan mengambil keputusan atas tingkah laku manusia. Ego juga disebut dengan eksekutif kepribadian, sebab ego adalah pengontrol pintu-pintu tindakan, dan memlilih kemana ia akan memberi respon, dan memutuskan kemana ia akan dipuaskan.

3. Superego merupakan aspek sosiologis yang merefleksikan nilai-nilai dan menyadarkan manusia. Pada hakekatnya superego termasuk hati nurani seorang yang menilai benar atau tidak akan perbuatan. Yang berarti bahwa superego mewakili nilai-nilai yang berotasi pada kesempurnaan.

Tidak hanya asek kepribadian yang ia cetuskan, namun Freud juga membahas terkait aktifitas mental individu yang terbagi dalam 3 tingkatan berdasarkan sejauh mana individu menyadari gejala-gejala psikis yang muncul (Semiun, 2006):

1. Tingkat kesadaran, pada tingkat ini aktivitas mental bisa disadari seperti, persepsi, berfikir.

2. Tingkat prasadar, pada tingkat ini bisa disadari apabila orangnya memperhatikan, misalnya memori, dan pengalaman bagus yang telah dipelajari.

3. Tingkat tidak disadari, biasanya tngkat ini gejala yang ditimbulkan ialah dorongan dari immoral, pengalaman yang memalukan, dorongan seksual yang tidak sesuai dengan keadaan masyarakat.

\section{Analisa Perspektif Sigmund Freud pada Kesehatan Mental}

Menurut psikoanalisis dalam buku Ramayulis, bahwa orang yang dikatakan sehat mental ialah orang yang tidak punya keluhan, seperti cemas, rendah diri, tegang dan sebagainya. Jadi menurut Sigmund Freud jika salah seorang mampu bergerak untuk melwan tekanan dan kecemasan, dengan belajar dan seimbangnya fungsi dari superego terhadap id dan ego, tidak mengalami gangguan dan penyimpangan pola mentalnya serta dapat menyesuaikan keadaan dengan berbagai dorongan dan keinginan (Ramayulis, 2002). Superego merupakan model personality yang kokoh dan kuat, merupakan kesempurnaan dari kesenangan. Maka dari itu, dianggap sebagai aspek moral kepribadian yang mendasar. Karna dalam kehidupan pribadi superego ini mengarahkan ke tujuan bahwa di dalamnya menyimpan nilai luhur yang tumbuh dari proses sosial masyarakat, sehingga menjadikan tenang dan damai. 
Jadi ketika dianalisa dengan menggunakan teori Sigmund, maka orang yang akan mempunyai dampak negatif dari poligami sirri tidak disebut sebagai gangguan mental, kecuali orang yang sering mengeluh, rendah diri dan cemas. Dan mental yang sehat ialah ketika seimbangnya fungsi dari superego terhadap id dan ego. Ada beberapa upaya yang dipakai untuk meningkatkan kesehatan mental yang dikupas oleh Sigmund Freud, diantaranya (Syeksnurjati.ac.id):

1. Metode asosiasi bebas, yang dimaksud di sini adalah semua klien diminta untuk menceritakan semua keluh kesah yang terlintas dalam pikirannya, meskipun hal tersebut Nampak sepele, tidak logis, tidak layak dan tidak relevan.

2. Metode analisis mimpi, Freud memandang mimpi adalah jalan utama menuju ke alam tak sadar, karena dia melihat isi mimpi yang ditentukan oleh keinginan-keinginan yang diproses. Karena mimpi juga bisa menafsirkan simbolis, dan isinya untuk merefleksikan pengalaman dari masa kanak-kanak awal. Dengan teknik seperti ini seorang bisa memperbesar pemahaman pasien atas penyebab dari gejala motivasional yang dialaminya (Koswara, 1991).

3. Metode analisis tranferensi, pada hakekatnya neurosis tranferensi ini bisa membantu terepeut untuk memproleh pemahaman atas cara pasien dengan cara mengamati. Menurut Freud, setelah pasien mengetahui arti sesungguhnya dari hubungan tranferensi dengan terapeutnya, si pasien akan memperoleh pemahaman atas pengalaman dan perasaan yang terjadi pada masa lalunya, dan menghubungkan pengalaman dan perasaan tersebut dengan kesulitan yang memandang dialami sekarang.

4. Reduksi, bukanlah termasuk teknik terapi, melainkan suatu upaya mendorong pasien supaya memperoleh pemahaman yang baru atas kehidupan barunya dan selanjutnya.

\section{KESIMPULAN}

Poligami sirri ialah pernikahan yang dilakukan tanpa adanya pencatatan perkawinan di lembaga yang berwenang. Pada akhirnya pernikahan ini tidak sah menurut hukum Negara namun sah dalam agama, tapi tidak memiliki kekuatan hukum dan akan sangat merugikan istri dan anak.

Bermacam akibat yang melanda kepada istri dan anak akan berdampak pada beban psikis, yakni akan adanya rasa malu, minder, anak tersebut merasa kurang percaya diri, rusaknya pergaulan anak dan jika dibiarkan dalam jangka panjang akan berdampak terhadap ketidak sehatan 
mental seseorang. Namun ketika dikaitkan dengan aliran Sigmund Freud tidak semua orang yang seperti itu dianggap lemah mental, karena ketika dikaitkan menurut pendapatnya orang yang bisa mengatasi tekanan dan kecemasan berarti orang tersebut mentalnya masih dianggap baik.

\section{DAFTAR PUTAKA}

Aulia, Nuansa (2011). Kompilasi Hukum Islam, Bandung: Nuansa Aulia.

Departemen Agama RI. (2000). Kompilasi Hukum Islam, (Jakarta: Dirjen Pembinaan Kelembagaan Agama Islam.

Koswara, E. (1991). Teori-teori Kepribadian, Bandung: PT. Eresco.

Ramayulis (2002). Ilmu Pendidikan Islam, Jakarta: Kalam Mulia.

Semiun. Yustinus (2006). Kesehatan Mental, Yogyakarata: Kansius.

Sopyan, Yayan. (2011). Islam Negara, Jakarta: PT Semesta rakyat Merdeka.

Suma, Muhammad Amin. (2008). Himpunan-himpunan Perdata Islam dan peraturan Pelaksanaan Lainnya di Negara Hukum Indonesia, Jakarta: Rajawali Pers.

Tjitrusudibio, Subekti, R. (1992). Kitab Undang-undang Hukum Perdata, Edisi Revisi, Jakarta: PT Pradya Pramita.

http//sc.syeksnurjati.ac.id., Tentang Kesehatan Mental Persepektif Sggmund Freud. Diakses pada 16 Mei 2020.

http://denisabila.wordpres.com-kesehatan-mental-menurut-aliranpsikoanalisa-amp. Diakses 17 Mei 2020. 